\title{
An Overview of Microfinance Service Practices in Nepal
}

\section{Puspa Raj Sharma, PhD}

\begin{abstract}
Microfinance is not simply banking for the poor; it is a development approach with a social mission and a private sector-based financial bottom line that uses tested and continually adjusted sets of principles, practices and technologies. The key to successful microfinance lies in the ability of the provider to cost-effectively reach a critical mass of clients with systems of delivery, market responsiveness, risk management and control that can generate a profit to the institution. Typically, this profit is ploughed back to ensure the long-term survival of the institution, i.e. the continuous provision of services demanded by its clients. The two long-term goals of microfinance are thus substantial outreach and sustainability. This article focus on microfinance services practices in Nepal on the basis of opinion survey.
\end{abstract}

Keywords: microfinance, outreach, sustainability, MDGs, Nepal

\section{Background Information}

The international community has made a strong commitment to the Millennium Development Goals (MDGs). Many donor agencies want to know whether microfinance, or financial services for the poor, is an effective tool for reaching the MDGs. In response, CGAP launched a study of the empirical evidence on the poor's access to financial services and how this access supports the MDGs. This brief summarizes the results of recent professional studies on the impact of microfinance, recognizing the difficulties of comparing studies that apply different levels of methodological rigor.

\section{Millennium Development Goals}

- Reduce the proportion of people living in extreme poverty by one-half.

- Enroll all children in primary school.

- Eliminate gender disparities in primary and secondary education.

- Reduce infant and child mortality rates by two-thirds.

- Reduce maternal mortality ratios by three-quarters.

- Provide access for all who need reproductive health services. 
- Reverse the loss of environmental resources.

Access to financial services underpins the ability of the poor to achieve the MDGs on their own terms in a sustainable way. Financial services enable the poor to increase and diversify incomes, build human, social and economic assets, and improve their lives in ways that reflect the multidimensional aspects of poverty. Evidence shows that poor people choose to invest in a wide range of assets: better nutrition, improved health, access to schooling, a better roof on their homes, and expansion of their small businesses.

The ability to borrow, save, and earn income enhances poor women's confidence, enabling them to better confront systemic gender inequities. Existing studies show that this empowerment takes different forms: In Indonesia, female clients of BRI were more likely than non-clients to make joint decisions with their husbands concerning allocation of household money, children's education, use of contraceptives and family size.

In India, SEWA clients have lobbied for higher wages, the rights of women in the informal sector, and resolving neighborhood issues. In Bangladesh, Bolivia, Nepal, the Philippines and Russia, clients of microfinance programs have run for local government office and won.

\section{Research Methods}

For the purpose of the study a survey was designed for collecting the data related to MFI's sustainability and its impacts. For the purpose of primary data collection a structured questionnaire survey was done. In this study the questionnaire was distributed to MFIs manager/field staff, and independent experts of related field. Besides this, focused group discussion with credit group of MFIs and in-depth interviews with chief of MFIs / Department (NPC, NRB, CMF, RMDC, NUB, SBB, PGBB, CGBB) were conducted

\section{Empirical Study}

The study explores various aspect and practices of microfinance services. The study focus on objectives of MFIs, client selection options, loan procedure, loan repayment and repayment status, factors contributing on high and low repayment rate, impact assessment practices and their problems, which are presented as follows:

\subsection{MFI s objectives and client selection option}

Operational objectives and plans include the product and services that a 
Microfinance institutions offers, its marketing and distributions arrangements, institutional resources and capacity to meet the target market and clients demand. In this backdrop, the study has tried to assess main preferences of MFIs.

Table 1: MFI Objectives Preferences and Preferences in the Client Selection

\begin{tabular}{|l|c|c|l|c|c|c|}
\hline \multicolumn{1}{|c|}{ Objectives } & Mean & Rank & Client selections options & Yes & No & Rank \\
\hline Generating income of the client & 2.40 & $\mathbf{1}$ & Poor and very poor & 34 & 6 & $\mathbf{1}$ \\
\hline Financial sustainability of MFI & 2.72 & $\mathbf{2}$ & Rural area & 25 & 15 & $\mathbf{2}$ \\
\hline Enterprises growth/job creation & 3.73 & $\mathbf{3}$ & Both new and existing business & 14 & 15 & $\mathbf{3}$ \\
\hline Women empowerment & 3.87 & $\mathbf{4}$ & New business & 10 & 30 & $\mathbf{4}$ \\
\hline Social improvements & 3.95 & $\mathbf{5}$ & Existing business & 8 & 32 & $\mathbf{5}$ \\
\hline Regional/sector development & 5.15 & $\mathbf{6}$ & Urban area & 9 & 31 & $\mathbf{6}$ \\
\hline Direct poverty alleviation & 5.23 & $\mathbf{7}$ & \multicolumn{2}{|c|}{ (Based on multiple choice) } \\
\hline
\end{tabular}

(Rank 1-7, 1 most important and 7 least important, $n=40$ )

Source : Field Survey

MFIs were asked to rank their objectives according to their preferences. The table showed that the most important objectives was generating income of the clients, followed by financial sustainability of the MFI. Regional sector development and direct poverty alleviation were ranked only sixth and the last rank.

It shows the general tendency of MFIs that give more emphasis on self-employment and income generating of the client and least priority to direct poverty alleviation. It may be deduced that in the name of poverty reduction they do not like to risk their institutions in respect to financial sustainability. MFI branch manages also opined that ultimately other objectives also contribute to the poverty alleviation.

\subsection{Client Selection}

Client selection is one of the most important aspects to fulfill their desired objectives. In above table, MFI clients' selections and their preferences showed mostly for poor and very poor and in rural areas rather than urban oriented new and existing businesses. It shows they were clear about the norms of Micro-finance. But a number of studies (Coleman, 1999, 2004; Amin et.al 2003; and Morduch, 1999) shows that the services of MFI is still not reached to hard core poor. Nepalese MFIs are not being able the poorest due to the inability of proper identification of the poor and lack of commitment and clear vision of their action (ADB/N, 2003). Despite the financial sector liberalization policy of the government 
aimed to encourage financial institutions to contribute in poverty reduction endeavor of the government, results have not been achieved satisfactory due to various challenges encountered by the MFIs all over the country. It shows a gap between theory and practice.

\subsection{Loan Procedure and Its Status in Various Aspects}

There are different products adopted for micro lending. Broadly speaking there are two types of micro lending accepted internationally. They are individual lending and peer lending (Harper, 2003). In Grameen Model most of MFIs have adopted peer lending except few cases. Loans are mutually guaranteed with other borrowers, potential clients are screened by their peers, little or no analysis is made of the business, loan size and term closely follows a determined gradual growth curve, and program staff have a distant relationship with large number of clients are the basic features of peer lending (Grameen Trust, 2002). In this study average size of loan and duration practice was evaluated and results are as follows:

Table 2: Average Loan Size and Duration

\begin{tabular}{|l|c|c|l|c|c|}
\hline \multicolumn{3}{|c|}{ Loan size } & \multicolumn{3}{c|}{ Duration of loan } \\
\hline Loan amount (Rs) & No. & Percent & Duration (months) & No. & Percent \\
\hline $5000-10000$ & 23 & 57.5 & $6-12$ months & 39 & 90.0 \\
\hline $10000-30000$ & 17 & 42.5 & l2-24 months & 1 & 10.0 \\
\hline Total & 40 & 100.0 & Total & 40 & 100.0 \\
\hline
\end{tabular}

Source : Field Survey

Most of the MFIs (90 percent) branch loan cycle falls on 1 year. The loan was to be paid within one year in the weekly or fortnightly installment. Majority (57.5 percent) of the branches average loan size per clients' falls under Rs. 5000-10,000 followed by 1000030,000 by 42.5 percent. It shows more emphasis on micro loan of the MFIs rather than the macro loan. In some of the cases, MFI have been running their micro-enterprises loan of Rs. 50,000 to Rs. 100,000 by taking sufficient collateral from the clients. This type of loan similar to traditional banking loan with collateral. Due to the collateral loan, it may increase the default rate of MFIs . The reason was that clients with collateral did not felt social pressure and MFIs may not able to strict monitored and control. MFIs were more attracted towards this type of loan for reducing their transaction costs. But if they followed collateral loan, it may degrades the image, values and norms of micro-finance and ultimately it will increase default rate and MFI may face the same problem of default loan and high volume 
of bad debts as two big commercial banks of Nepal faced (RBB and NBL).

\subsection{Loan Repayment Rate and Dropout Status}

Grameen type lending procedure group size was strictly fixed at 5 and group formation was used as a means to introduce social changes. Mainly Grameen Replicator in Nepal does micro lending by forming Grameen type of soldiery groups. Micro-finance is considered not only as providing credit it used as a tool of social transformations. In this process, repayment rate was considered as one of the crucial aspects of group effectiveness. In the study the respondents were requested to estimate their loan repayment rate, which are as follows:

Table 3: Estimation of Average Loan Repayment Rate and Dropout Status

\begin{tabular}{|l|c|c|l|c|c|}
\hline Repayment status & No. of cases & Percent & Dropout rate & No.of cases & Percent \\
\hline Less than 90\% & 1 & 2.5 & Less than $10 \%$ & 15 & 37.5 \\
\hline $90 \%-95 \%$ & 2 & 5.0 & $10 \%-20 \%$ & 19 & 47.5 \\
\hline $95 \%-98 \%$ & 3 & 7.5 & $30 \%-50 \%$ & 3 & 7.5 \\
\hline More than 98\% & 34 & 85.0 & $50 \%$ and above & 1 & 2.5 \\
\hline Total & 40 & 100.0 & No dropout & 2 & 5.0 \\
\hline
\end{tabular}

Source : Field Survey

Majorities (85\%) of the branches have more 98 percent repayment rate. The result shows that the repayment rate of selected MFI is sound. Mostly MFI did not have to face arrears amount of loan, which was also matched with their financial reporting and analysis. But one of the experts (taking responsibility of apex institution) raised doubt towards MFI's reporting. MFIs showed positive aspect only for taking and renewing loan from the wholesale lending agency but the reality may have been different, as opined by him.

\subsection{Dropout Status}

Performance of an institution is for meeting goals. Sustainability is meeting goals now and in the long run (Schreiner, 1997). To achieve sustainability, MFIs have to focus their attention on dropout rate from their program. The higher dropout rate is the signal of dissatisfaction or the graduation from the program (Yunus, 2003). It threatens the viability and sustainability of the program that are not kept it under control.

In this backdrop, majority of the branches have (47 percent) faced 10-20 percent drop out, followed by 37.5 percent facing less than 10 percent drop out. It means the MFI services may not exactly match with the needs of the clients. The causes of dropout 
considered by the members opined in focus group discussions were: small size of loan, graduation of the clients, alternative income of the clients, migration, husband absent at home, lack of time for weekly meeting, strict disciplinary rules of MFI and duplication of the clients.

Thus sustainability of a group is influenced by a host of factors, such as successful leadership, regular meeting of groups and active participation of members, group saving, benefits perceived and actually realized by the members, adequacies of loan, enhancement and income generation. However, the critical factor that makes group members intrinsically associate with the group is the earning of additional income from activities carried out by micro-finance.

\subsection{Factors Contributing High Repayment Rate}

Loan delinquency has become a serious problem faced by the formal financial institutions. Delinquency of loan may affect on interest collection, portfolio management, staff motivation, and clients' behavior, operating cost and loan loss provision. The general thinking is that poor people do not repay loans and they can not pay interest rate high enough to cover the costs of their loans. But modern MFIs of Bangladesh (GBB, ASA, BRAC, PROSHIKA etc.) and some grameen replicators of Nepal have already proved the credibility of poor and demolish the negative beliefs toward poor. Therefore to explore the factors contributing high repayment rate, the respondents were asked and the result are as follows:

Table 4: Factors of High Repayment Rate and Low Repayment Rate Situation

\begin{tabular}{|c|c|c|c|c|c|}
\hline $\begin{array}{l}\text { Factors contributing high } \\
\text { repayment rate }\end{array}$ & Mean & Rank & $\begin{array}{c}\text { Factors contributing for low } \\
\text { repayment }\end{array}$ & Mean & Rank \\
\hline Group peer pressure & 1.90 & 1 & $\begin{array}{l}\text { Mis-utilization of loan/ } \\
\text { contingency situation }\end{array}$ & 1.67 & 1 \\
\hline $\begin{array}{l}\text { Systematic group selection/ } \\
\text { basic training }\end{array}$ & 2.03 & 2 & $\begin{array}{l}\text { Unsuitable micro finance product } \\
\text { (terms and conditions) }\end{array}$ & 2.05 & 2 \\
\hline $\begin{array}{l}\text { Regular follow up and } \\
\text { monitoring of MFI }\end{array}$ & 2.75 & 3 & $\begin{array}{l}\text { Lack of regular follow up/ } \\
\text { duplication problems }\end{array}$ & 2.88 & 3 \\
\hline $\begin{array}{l}\text { Strict rule of apex/ } \\
\text { wholesale institutions }\end{array}$ & 3.80 & 4 & Marketing problem of output & 3.67 & 4 \\
\hline Client future access to loan & 4.30 & 5 & Negligence in group formation & 2.68 & 5 \\
\hline Forced/voluntary saving & 4.80 & 6 & High interest rate and penalty & 4.8 & 6 \\
\hline Low interest rate & 5.20 & 7 & Investment without collateral & 5.35 & I \\
\hline
\end{tabular}

(Rank 1 to 7, 1 most important and 7 least important) 
Source : Field Survey

Regarding the causes of high repayment rate in MFIs, group peer pressure followed by systematic group selection have emerged as the first and second reasons respectively. Client's future access to bigger loan, forced/voluntary saving of the client and low interest rate charged by the MFIs were ranked at fifth, sixth, and the last place respectively.

The result shows that the modern MFIs are capable for successful lending without any collateral from the client. The design of micro finance schemes and its lending procedure determine the loan repayment performance of the MFI.

\subsection{Factors Contributing Low Repayment Rate}

The respondents were also asked about, in what situation would they get normally low repayment. As presented in the table, mis- utilization of loan/ contingency situation followed by unsuitable micro finances schemes are placed first and second respectively. High interest rate and penalty, and investment without collateral were placed sixth and the last position respectively. It means mis- utilization aspect of loan should be discouraged by designing suitable micro finance schemes for them backed up by regular monitoring and follow up. The cause of non-repayment was not found to be collateral, generally given high preference by the traditional banking.

\subsection{Impact Assessment Practices}

Periodic evaluation of the impact of MFI can optimize the limited resources of MFI (Yunus, 2003). The impact assessment of micro-finance program evaluate the gap between the desired outcome and actual outcome, without great loss to the institutions Periodic assessment may help to rectify the shortcomings immediately. There is no formal impact assessment program in the selected MFIs. However, this study, tried to explore existing practice of impact assessment and its indicators at the enterprise and the individuallevel.

Table: 5 Impact Assessment Indicators on Individual and Enterprises Level

\begin{tabular}{|l|c|c|l|c|c|}
\hline $\begin{array}{c}\text { Impact Assessment Indicators } \\
\text {-Individual level }\end{array}$ & Mean & Rank & $\begin{array}{c}\text { Indicators- Enterprises } \\
\text { Level }\end{array}$ & Mean & Rank \\
\hline Income and employment & 1.28 & $\mathbf{1}$ & Employment creation & 2.10 & $\mathbf{1}$ \\
\hline Saving and asset accumulation & 1.30 & $\mathbf{2}$ & Sales/profit & 2.18 & $\mathbf{2}$ \\
\hline Empowerment (education) & 1.50 & $\mathbf{3}$ & Asset accumulation & 2.13 & $\mathbf{3}$ \\
\hline Changes in attitude and knowledge & 1.60 & $\mathbf{4}$ & Produced output & 3.62 & $\mathbf{4}$ \\
\hline
\end{tabular}

(Rank 1 to 4, 1 for most important and 4 for least important)

Source : Field Survey

MFIs did not appear to emphasize impact assessment. In case of impact assessment 
held at individual level, income and employment, saving and asset accumulation, empowerment, changes in attitude and knowledge, were ranked from first to fourth respectively. Similarly at the enterprise level employment creation, generated income/ sales, asset accumulation, and engaged production output were ranked as indicators from first to fourth respectively. It shows the different basis of impact assessment at enterprise and individual level.

\subsection{Result of the Impact}

The respondents were asked about the level of impact normally seen either on individual level or at enterprises level. The results were as follows:

Table 6: Result of Impact Normally Observed

\begin{tabular}{|l|c|c|}
\hline \multicolumn{1}{|c|}{ Result of impact normally observed } & No.of cases & Percent \\
\hline Enterprises level & 6 & 15.0 \\
\hline Borrower level & 30 & 75.0 \\
\hline Both enterprises and borrowers & 4 & 10.0 \\
\hline Total & 40 & 100.0 \\
\hline
\end{tabular}

Source : Field Survey

As presented in the table, majority ( 75 percent) opined that the impact could be seen at borrower level followed by enterprises level ( 15 percent) and both in enterprises and individual level (10 percent). It shows that the impact is mostly observed at individual level rather than at enterprise level. The main cause may be due to small loan size and generally for a very short period (maximum for one year).

\subsection{Objectives of the Impact Assessment}

The respondents were asked about the probable objectives of the impact assessment, which were opined as follows

Table 7: Objectives of the Impact Assessment

\begin{tabular}{|l|c|c|}
\hline \multicolumn{1}{|c|}{ Objectives } & No. of Cases & Percentage \\
\hline Learn about program effectiveness & 20 & 50 \\
\hline Research on market and client need & 10 & 25 \\
\hline Fund optimization & 8 & 20 \\
\hline Do not know & 2 & 5 \\
\hline
\end{tabular}

Source : Field Survey 
Majority of the respondents cited learning about the program effectiveness as their main reason for impact analysis followed by researching the market and clients as the second reason of impact assessment. The least reason found to be for fund optimization.

\subsection{Factor Preventing Impact Assessments}

Currently MFIs did not seem to be conducting impact assessments of their activities and program. In this perspective, they were asked about the main problem in impact assessments:

Table 8: Factor Preventing Impact Assessments

\begin{tabular}{|l|c|c|c|}
\hline \multicolumn{1}{|c|}{ Main factors } & Mean & Std. Deviation & Rank \\
\hline Lack of staff/expertise & 3.62 & 2.07 & $\mathbf{1}$ \\
\hline Funding for the work & 3.87 & 2.10 & $\mathbf{2}$ \\
\hline Lack of clear baseline survey & 3.90 & 2.31 & $\mathbf{3}$ \\
\hline Unclear objectives of MFI & 4.00 & 2.15 & $\mathbf{4}$ \\
\hline Transparency problem & 4.08 & 1.70 & $\mathbf{5}$ \\
\hline Accounting problem & 4.18 & 2.08 & $\mathbf{6}$ \\
\hline Cooperation of client & 4.80 & 1.75 & $\mathbf{7}$ \\
\hline
\end{tabular}

Source : Field Survey

As presented in the table, lack of staff and expertise followed by funding for the works were reported as the first and second factors inhibiting impact assessment. Similarly accounting problem and cooperation of the client were rated as the sixth and seventh preventing assessments respectively.

It shows that MFIs may not have any special staff, expertise and financial resources for impact assessment and there is no compulsion of impact assessment from the regulatory point of view.

An effective apex micro-finance institution could play an important role in ensuring the effective channeling of funds to targeted NGOs/MFIs and borrowers at reasonable interest rates. Sustainability of the micro-finance sector is important and should be the ultimate goal of any strategy to strengthen the sector.

\section{Conclusions}

Micro-finance leads to social and economic changes in the borrowers after the 
participation in the programs. Increasing income among borrowers results increase in food sufficiency, consumption of nutrient food, good caring of children health, health awareness and preventive measures of health, good education of the children, repair and maintenance of home.

Involvement in the MFIs program increases in income and associated with increases in saving, investment and asset accumulations. Clients have alternative sources of financing and need not to depend upon moneylenders. Comparatively the borrowing was possible at low rate of interest.

Increase in income leads to an improvement in consumption pattern, the study show microfinance leads to an increase in expenditure on human capital. The sustainability capacity of the MFIs has been improving gradually, which was backstopping by its clients positive social and economic changes, empowerment of women, cost recovery of the MFIs branches and their increasing outreach.

Credit plus approach provides an effective and cost-effective model for creating sustainable enterprises among the poor, the ultra poor, and the severely socially excluded. There is considerable potential for scaling up of the process. Gradual improvements in the leadership, institutional arrangement, regularity and policy framework, level of outreach, macro-economic environment, players of micro-finance services and MFIs' productivity is leading to overall development in micro-finance creating an environment for poverty alleviation and rural development. Overhead and office expenses per clients also high in Nepal. The overall productivity of Bangladesh's MFIs was in better than in Nepal.

The success stories have been highlighted by most impact assessment studies, the weaker areas received less attention. Lack of scope for profitable activities in some is pronounced. There is only a limited opportunity and scope for trading activities in the local areas through small size of loans. Livestock and agriculture sector have less attraction. Micro-finance is less successful due to scanty settlements in the hills and mountains. Cases have been reported of using loans for consumption purposes. The loan given to women is used and controlled by male members in the family. In some cases, women had extra burden and tension from the program. Females are used only to get loans and males actually control the loan. Natual and manmade calamities and health risk seriously effect empowerment. MFIs usually flows to better off among the poor households and the hard core poor do not have access to micro-finance services, which is against the norms of the programs.

Thus micro-finance has the potential to have a powerful impact on poverty reduction and women's empowerment. However, micro-finance is not a panacea in itself. Other issues 
of development policy and implementation, which effect women empowerment, poverty reduction, and utility of micro-finance need to be addressed at proper and appropriate levels.

\section{Recommendations for Future Policy Directions}

On the basis of this research study the followings recommendations are made to improve micro-finance services for substantial contribution on poverty reduction and sustainability of the MFIs.

- The government should formulate a national policy of microfinance setting the vision objectives, strategies and policies and specifying implementation modalities to direct the micro finance program to accomplish the stipulated objectives.

- To expand the additional outreach of microfinance services, it is recommended that poor, who are still outside the services should be identified by extensive household survey. There should be no confusion regarding the target clients. Existing NGO and MFIs should be mobilized in this process.

- To increase the outreach of existing MFIs, the government, INGO/ Donor agency should subsidize social costs of MFIs either on clients' basis or on time basis until and unless they reach a level of operating self-sufficiency as these border mission is beyond the goals or capacity of the MFIs alone. The culture of long term subsidy should be discouraged and ultimately it should be directed towards financial selfsufficiency for their sustainability in the long run.

- To create healthy competition among MFIs the problem of duplication among institutions should be avoided immediately. For this local co-ordination network of MFIs should be established by incorporating credit information of the new clients.

- In order to increase clients serving capacity of the MFIs proper planning and implementation clarifying the authority and accountability of each branch and staffs should be prepared and monitored time to time effectively.

- The motivation level of the field staff should be maintained at high level, they are the "key scorers" of the micro-finance game

- To increase the enterpreneurship and business skill of the clients vocational and skill enhancement training should be emphasized, since credit without skills may not be sustainable in the future. For this there should be proper co-ordination with training delivery government and non-governmental institutions at national, regional and local level. Basic training at the beginning of the program should be 
intensive, it should not be used only for formality for taking credit.

- Credit plus approach provides an effective and cost-effective model for creating sustainable enterprises among the poor, the ultra poor, and the severely socially excluded, so government and central bank should formulate the policy and program of credit plus approach of micro-finance specially for the deprived and hard core poor.

- To minimize the vulnerability and risk of the client's micro insurance schemes and products should be designed by addressing the need of the clients. Awareness building program should be launched time to time regarding rules, terms, conditions and provisions of the services.

- To strengthen the internal resources of the MFIs, saving schemes should be diversified. There should not be wide gap between saving interest rate and lending interest rate in the name of microfinance services. MFIs should be alert about the competitors and market rate of interest. The effort of MFIs should always be to minimize their transaction costs.

- The existing outreach of MFIs is focused on terai and hilly urban areas rather than the mountain and rural hills. The government should design a special program with the provision of subsidies for meeting operational costs in order to motivate the MFI's to implement microfinance programs in the remoter mountain and hill areas. Besides, the MFIs should promote the local NGOs and Cooperatives to make them capable of carrying out micro-finance program in their areas. Such NGOs and Cooperatives would be more cost effective and locally oriented than the MFIs from outside.

- The working procedure in the Grameen modality should be reviewed by interacting with the clients like weekly installment may be changed to fortnightly or monthly according to the need and desire of the clients

- The cause of drop out should be analyzed properly and if the causes are within the control of MFIs, then it should take necessary action immediately.

- WGBB has emphasized more on collateral loan in the initial period, due to which financial position seems to be better. But actually MFIs should not over emphasize on collateral lending. It will degrade the image and norms of microfinance institutions and it may increase the default rate and cause low repayment rate in the long run.

- Impact assessment programs should be introduced periodically in program specific areas. It will help the MFIs to identify the weaknesses and to rectify in their 
saving lending policy .

- Privatization of MFIs should be emphasized. The central bank's main role should not be as implementers or operators, its main role is to supervise operations. If the GBB are privatized, the majority shares may be given to already institutionalize private sectors MFIs.

- Managerial aspects of MFIs should be strengthened. Managerial aspect like planning, communications, management information system and financial management need to be substantially improved in government initiated MFIs if they are really to be sustainable.

- In some cases in the name of women, the resources are controlled by men and. To cater to such problems, awareness among women should be promoted individually and collectively.

- The government should constitute a micro-finance apex body consisting of representatives from NPC, NRB, MOF and MFIs as well as micro-finance specialist /expert to execute national micro finance policy. It should also have authority to coordinate, supervise and monitor the activities and credit operations of MFIs. This body may also be authorized to create microfinance fund by pooling the resource avabilabe from the government as well as donor communities and use the fund to provide credit to MFI and NGOs.

- MFIs should establish /set norms for i) return on APA, ii) ratio of financial cost and operating cost to APA, number of loan to motivators, outstanding portfolio to motivators, motivators to total staff and loan size, and iii) amount of transactions to be carried out at a given level of expenditure for their sustainability. They should monitor and evaluate their status and performance periodically against the establish benchmarks.

- MFIs should be deeply rooted in micro-finance culture and feeling of compassion, empathy and concern to the poor. This will reorient them their programs towards serving the poor. Compared to Bangladesh Nepal lag far behind in operation though institutions have been created in similar lines.

- NRB and the Government of Nepal should initiate monitoring and supervision of wholesale lending institution to control fund parking and lending wholesale ledewrs to activise resources more extensively, Otherwise it will be injustice to hold fund in fixed account for interest income, which is directly affects the overall microfinance environment. 
- The wholesale lending institutions are working in limited area only To increase the outreach of whole-sale lending, private sector MFIs may be promoted as wholesale agencies to deliver credit in the rural areas. Since these institutions have long experience and network in the field of micro-finance particularly in Western and Central regions.

- The limit of Rs. 30,000 as microfinance loan set by NRB should be increased as per the changing need of the clients and the level of inflation.

- $\quad$ NRB need to review policies of MFIs and provide permission of collecting deposit to MFIs from non-members like in Bangladesh. It will generate greater fund circulation in the rural areas and fulfill the resource need for financial institutions

\author{
Abbreviations \\ MDG : Millennium Development Goals \\ MFIs : Microfinance Institutions \\ NRB : Nepal Rastra Bank \\ MOF : Minstry of Finance \\ NPC : National Planning Commission \\ RMDC : Rural Microfinance Development Center \\ NUB : Nirdhan Utthan Bank \\ SBB : Swabalamban Bikash Bank \\ CGBB : Central Grameen Bikash Bank \\ NGOs : Non-governmental Organizations
}

\title{
REFERENCES
}

Agrawal, G.R. (2003). Critical issues and poverty reduction through rural credit in Nepal. Agriculture Credit, 30. Agrawal, G.R. (2005).Rural entrepreneurship and agricultural development bank. Agriculture Credit, 38.

Ahmed, M. (2002). Key to achieving sustainability. Dhaka: ASA's Publication.

Asian Development Bank (ADB) (2002). Finance for the Poor, 3 (2).

Asian Development Bank (ADB) (2002). Poverty reduction in Nepal: Issues, findings and approaches. Manila: ADB.

Asian Development Bank (ADB) (2003). Finance for the poor: Microfinance development strategy. Manila: ADB

Asian Development Bank (ADB) (2005). The role of central banks in micro-finance in Asia and the Pacific. Manila: ADB

Bajracharya, P. (2003b). Micro and small enterprises: An integrated and project report on policy review. 


\section{MEDEP/UNDP.}

Bajracharya, P., \& Bajaracharya, S. (2005 Jan). Total factor productivity growth in Nepal -An estimate. Agriculture Credit, 38

World Bank, CGAP. (2001). Micro and small enterprises finance guiding principles supporting intermediaries, Washington D.C: Author.

World Bank, CGAP (2003). Anatomy of micro-finance deal: A new approach to investing in micro-finance institutions. Focus Note. Washington D.C: Author

Christensen, G. (1993). The limits of informal financial intermediation. World Development, 21(5): 721-731.

Dhakal, N. H. (2004 Jan). Micro-finance for achieving millennium development goals in Nepal. Agriculture Credit, 37.

Hossain, M.(2002). Credit for the rural poor, the experience of grameen bank in Bangladesh. Research Report. Washington D.C.: IFPRI and BIDS.

Hulme, D., \& P. Mosley. (1996). Finance against poverty, I\&II. London: Routledge.

Khandker, S.R. (2003). Micro-finance and poverty: Evidence using panel data from Bangladesh. World Development, 31 (3): 647-665

Kidder, T. (1997). Macro debates at the micro-credit summit. Development in Practice, 7 (4): 432-439.

Ledgerwood, J. (1995). Philippines poverty strategy report: Access to credit for the poor. Washington D.C.: World Bank.

Ledgerwood, J. (1997 Mar). Critical issues in Nepalese micro-finance circumstances. Maryland: IRIS Center. Morduch, J. (1999 b). The Micro-finance promise. Journal of Economic Literature, XXXVII (4): 1569-1614. Ostergaard, L.1992). Gender and development : A practical guide. London: Routledge.

Rhyne, E. , \& Maria, O. (1994). A financial system approach to micro-enterprises GEMINI. Working Paper 18, Washington D.C.

Robert, G. (1990). The informal financial sector in Bangladesh: An appraisal of its role in development. Development and Change, 23:147-68.

Robinson, M.S.(1996). Addressing some key questions on finance and poverty. Journal of International Development, 8(2):153-61.

Schmidt, R. H., \& Claus-Peter, Z. (1996). Prospects, problems and potential of credit granting NGOs. Journal of International Development, 8(2): 241-58.

Schuurman, F.J. (1993). Beyond the impasse: New directions in development theory. London : Zed. Books.

Sharma, P. R. (2003a Dec). Micro-finance programs and delinquency management in Nepal. Comment Paper on the paper presented in a seminar organized by SAP-Nepal, Pokhara.

Sharma, P. R. (2004 Jan). Entrepreneurship competency development program : A case study of Pokhara submetropolitan city. The Journal of Business and Management, 2(1).

Sharma, P. R. (2004 Jul). Micro-finance programs and its sustainability in Nepal. Paper presented in a seminar organised by SAP-Nepal, Pokhara

Sharma, P. R. (2004). Micro-finance: A powerful tool for social transformation, its challenges and principles. The Journal of Nepalese Business Studies, 69-74.

Sharma, P. R. (2006). Micro-finance and its service development: Challenges and opportunitiy in Nepal. Banijya Sansar, (12).

Sharma, P. R. (2003 Dec). Micro-finance programs and its strategy to deliver services on poorest of the poor in 
Nepal. Paper presented in a seminar organized by South Asia Partnership - Nepal, Pokhara.

Sharma, P. R. (2004). Millenium development goals and international year of micro-finance 2005 in the context of Nepal. The Journal of Nepalese Business Studies, 2(2).

Sharma, S.R. (2003). Micro-finance against poverty: The Nepalese scenario. Economic Review, Occasional paper, 15. Nepal Rastra Bank, Nepal. Taylor, G. (1989). The Student's Writing Guide. Cambridge: CUP.

Turabian, K.L. (1996). A manual for writers of term papers, thesis, and dissertations (6th ed.). Chicago: University of Chicago Press.

Wolf, H. K., \& Pant, P. R.(2002). A handbook for social science research and thesis writing (3rd ed.). Kathmandu: Research Division, Tribhuvan University

World Bank, (2002). World development report 2002/2003, attacking poverty. New York: Oxford University Press

Weissberg, R., \& Buker, S. (1990). Writing up research: Experimental research report writing for students of English. New Jersey: Prentice Hall, Englewood Cliffs.

Wright, G.A.N.(1999). Examining the impact of micro-finance services: Increasing income or reducing poverty. Small Enterprise Development, 10 (1): 39-47.

Yunus, M. (2002). Grameen Bank II : Designed to open new possibilities? Grameen Dialogue. Dhaka: Grameen Bank, Mirpur, Bangladesh.

Yunus, M. (2003). Halving poverty by 2015: We can actually make it happen? Dhaka: Grameen Bank, Mirpur, Bangladesh 